\title{
Growth factors and their cellular actions
}

\author{
David J. Hill* \\ Department of Paediatrics, University of Sheffield, Clinical Sciences Centre, Northern General \\ Hospital, Sheffield S5 7AU, U.K.
}

Keywords: growth factors; growth; embryogenesis; differentiation; ovary

\section{Introduction}

Normal tissue growth involves a complex interaction of cell proliferation, hypertrophy, migration, differentiation and senescence which proceeds within strict temporal and anatomical constraints. While classical endocrine hormones such as growth hormone and thyroxine can influence the overall rate of growth and maturation they do not contribute to the fundamental intercellular signalling within tissues that underlies these processes. This appears to be the primary role of peptide growth factors. During the rapid development of the embryo and fetus peptide growth factors are associated with tissue induction, the clonal growth of stem-cell populations, and the appearance of differentiated function in the presumptive organs. In post-natal life the actions of growth factors are less obvious although notable exceptions demonstrate that the same biological pathways exist; the best studied examples are the role of somatomedins during longitudinal skeletal growth and the coordinated actions of several growth factors within the ovarian cycle, during testicular function, and during peripheral wound healing. The aim of this article is to present a broad overview of the diverse presence and actions of peptide growth factors during human development and reproduction.

\section{Physical form and anatomical location}

Those peptide growth factors that have been best characterized are shown in Table 1 . They are typically proteins of molecular weight $<30000$ which are synthesized and act within the local tissue environment as paracrine or autocrine hormones. Unlike classical endocrine hormones each growth factor may be synthesized by many anatomically diffuse tissues. They are not stored intracellularly in granules and release is largely dependent on de-novo synthesis. While acute release is not common this has been overcome during wound healing by the rapid delivery of several growth factors to the sites of tissue damage by platelet lysis. Peptide growth factors interact with receptors located on the cell membrane which are usually glycoproteins and which communicate with secondary messenger systems by conformational changes. This often involves the autophosphorylation of tyrosine residues located on the intracellular domain of the receptor. The second messenger systems utilized are diverse and include changes to intracellular calcium levels, cyclic AMP, cellular alkalization, and phosphoinositol metabolites. The net biological events induced by growth factors are, however, remarkably consistent and include a rapid stimulation of amino acid transport, glucose uptake and utilization, and RNA and protein synthesis. For many, but not all, growth factors this is followed by DNA synthesis and cell replication.

\footnotetext{
*Present address: Lawson Research Institute, University of Western Ontario, St Joseph's Hospital, 268 Grosvenor St, London, Ontario, Canada N6A 4V2.
} 
The somatomedins or insulin-like growth factors (IGFs) are single chain polypeptides of $M_{\mathrm{r}} \sim 7500$ which share structural and functional similarities with insulin. Two peptide species exist; IGF-I which has 70 amino acids and is encoded by a gene on human chromosome 12, and IGF-II which has 67 amino acids and derives from a gene on the short arm of chromosome 11 (Tricoli et al., 1984). The IGFs are potent mitogens for cells derived from all primitive germ layers. In postnatal life the IGF-I gene is under tight transcriptional control by growth hormone, circulating concentrations being severely reduced in hypopituitarism and elevated during acromegaly. While the major source of IGFs was originally thought to be liver it is now recognized that they are synthesized by most body tissues both before and after birth (D'Ercole et al., 1984; Rotwein et al., 1987).

The IGFs appear early in embryogenesis during and after the condensation of presumptive organs and tissues, and their primary role may be to promote the clonal expansion and subsequent differentiation of stem cell populations. Messenger RNA for IGF-II was identified in embryonic chick eye, heart and wing bud mesenchyme while IGF peptides have been localized, using immunohistochemistry, to the mesencephalon, lens, neural tube, myotome and developing wing buds at 3-4 days incubation (Engstrom et al., 1987; Rolfe et al., 1988). In the rat embryo mRNA for IGF-II was localized by cDNA/mRNA in-situ hybridization to yolk sac, hepatic bud, branchial arch mesoderm, and dermato-myotome between 10.5 and 14.5 days of gestation, and was additionally present in differentiated muscle, perichondrium, chondrocytes and gut epithelium in later gestation (Beck et al., 1987). In the human fetus in the early second trimester, IGFs were localized by immunohistochemistry to epithelia within the gut, kidney and lung; hepatocytes, adrenal cortical cells from the fetal zone, differentiated skeletal and cardiac muscle fibres, haemopoietic tissue and dermal skin (Han et al., 1987b). This distribution may depend on an association with specific IGF binding proteins which share a similar cellular distribution (Hill et al., 1988). The binding proteins may contribute to a sequestration of IGF peptides within certain cell populations, since analysis of IGF-I and -II mRNA distribution in human fetal tissues by in-situ hybridization suggested that the majority was present in fibrous mesenchymal tissues adjacent to the cell types positive for IGF peptides (Han et al., 1987a).

In post-natal life IGF peptide presence is less apparent in many tissues by immunohistochemistry compared to the fetus, but can be re-expressed when local damage is inflicted on skeletal muscle, vascular endothelium, hyaline cartilage or peripheral nerves (Hansson et al., 1986, 1987; Jennische \& Oliverecrone, 1987). However, a strong expression of IGF peptides is retained in those tissues which continue to undergo rapid growth and differentiation, including the epiphyseal growth plate cartilage, testis and ovary. Within the cartilage growth plates of the long bones IGF-I is synthesized by proliferative chondrocytes but this ceases once cells have hypertrophied and become post-mitotic before matrix calcification (Isaksson et al., 1987). The expression of IGF-I within growth plate cartilage is largely dependent on the presence of growth hormone. IGF-I is likely to act as a paracrine or autocrine agent within growth plate cartilage to promote the clonal expansion of newly-formed chondrocytes and their subsequent differentiation. Within the rat testis IGF-I is released from Sertoli cells and is also located within spermatocytes (Andersson et al., 1986; Smith et al., 1987). In the rat ovary IGF-I mRNA has been localized by in-situ hybridization to the granulosa cells surrounding the follicles, expression being greatest around the dominant follicles (Oliver et al., 1988). Human follicular fluid is a rich source of IGF-I which, in cohort follicles, correlates with that in the circulation. Concentrations are greatest in the dominant follicles and increase further following the LH surge, after which they correlate positively with oestrogen concentrations (Eden et al., 1988). IGF-I is released by isolated rat granulosa cells, this being enhanced by GH or FSH and further augmented by oestradiol (Hsu \& Hammond, 1987).

Epidermal growth factor (EGF) is a single chain polypeptide of 53 amino acids with molecular weight of 6000 . Mouse EGF was first isolated from male submaxillary glands and the equivalent human peptide, urogastrone, from urine (Cohen, 1962; Gregory, 1975). A structural analogue of EGF is transforming growth factor- $\alpha$ (TGF- $\alpha$ ). This has a molecular weight of 7500 and shows a 
Table 1. Peptide growth factors

Insulin-like growth factors/

somatomedins

Epidermal growth factor

Transforming growth factor $\alpha$

Fibroblast growth factor

Transforming growth factor $\beta$
IGF-I and -II

EGF

TGF $-\alpha$

Acidic FGF Basic FGF

PDGF

TGF- $\beta$
Mitogen and differentiating agent for cells derived from all primitive germ layers.

Mitogens for epithelial and mesodermal tissues. Inhibit differentiated function in ovary. Enhances maturation of skin and teeth. Promotes release of hCG and placental lactogen from placenta.

Mitogen for mesodermal and endodermal cell types. Induces mesoderm formation in Xenopus embryo. Inhibits differentiation in muscle but potentiates hormone release in pituitary. Causes angiogenesis.

Mitogen for mesodermal cell types. Chemotactic for fibroblasts, smooth muscle cells, monocytes and neutrophils.

Inhibitor of epithelial cell proliferation but biphasic action on mesodermal cell types. Induces mesoderm formation on Xenopus embryo. Inhibits differentiation in muscle. Chemotactic for monocytes, and fibroblasts. Promotes fibronectin and collagen synthesis.

$30-40 \%$ amino acid homology with EGF (Marquardt et al., 1984). TGF- $\alpha$ reproduces all of the biological actions of EGF and interacts with the EGF receptor. EGF is a potent mitogen for epithelial and mesodermal cell types in vitro, including connective tissues, glial cells and ovarian granulosa cells. In the mouse embryo EGF receptors appear with the first differentiated cell type, trophoectoderm (Adamson \& Meek, 1984). It is unclear whether the peptide that might activate these receptors is EGF or TGF- $\alpha$. Although TGF- $\alpha$ was detected in the mouse embryo with the highest levels on Day 7 of gestation, in-situ hybridization studies in rats suggested that the embryo does not express TGF- $\alpha$ at this time (Han et al., 1987c). However, abundant TGF- $\alpha$ mRNA was present in maternal decidua, especially adjacent to the embryo. Decidual expression appeared after implantation, peaked at Day 8 and slowly declined to Day 15 in parallel with decidual resorption. Peak levels of TGF- $\alpha$ may therefore be available to the embryo from a maternal source during gastrulation and neurulation. Early in the second trimester, EGF is present in the human fetus within cells at the base of the gastric and pyloric glands in the stomach, the Brunner's glands in the duodenum, the epithelium of the distal convoluted kidney tubules, anterior pituitary, pseudostratified columnar epithelium of the trachea and the placenta (Kasselberg et al., 1985). In post-natal life also, EGF is detectable by immunohistochemistry in association with epithelial layers demonstrating rapid turnover, such as in gut and skin. Additionally, it is stored in large quantities in platelets and released during tissue injury. Similarly, its presence within monocytes may be related to wound healing.

Fibroblast growth factor (FGF) has been isolated from bovine pituitary and brain in both an acidic (pI 4.5) and basic (pI 9.6) form, each being of $M_{\mathrm{r}} \sim 16000-17000$ (Gospodarowicz et al., 1984; Esch et al., 1985). FGFs are potent mitogens for tissues derived from mesenchyme or neuroectoderm such as chondrocytes, fibroblasts, myoblasts, glial cells, adrenal cortex and ovarian granulosa cells (Gospodarowicz et al., 1987). They are the most effective mitogens so far identified for vascular endothelial cells, and additionally promote cell migration, invasion and the production of plasminogen activator; all necessary features of angiogenesis in vivo. FGF mRNA is detectable in the Xenopus blastula (Kimelman \& Kirschner, 1987) while the peptides are present in chick embryo brain, retina and vitreum from Day 11 of gestation. In adult life FGF is diversely distributed among tissues including ovary, adrenal, kidney and the anterior pituitary.

Platelet-derived growth factor (PDGF) was first identified within the $\alpha$ storage granules of platelets. Human PDGF is a highly basic glycoprotein (pI 10.2) with two biologically equipotent variants, PDGF 1 which contains $7 \%$ carbohydrate and has a molecular weight of 31000 , and PDGF 2 with $4 \%$ carbohydrate and molecular weight 28000 (Deuel \& Huang, 1984). In platelets 
both forms contain an A-chain of $M_{\mathrm{r}} 15000-17000$ and a B-chain of 14000 linked by disulphide bridges. The B-chain of PDGF shows extensive sequence homology with the viral p28 protein encoded by the v-sis oncogene (Waterfield et al., 1983), and the cellular sis gene was subsequently shown to encode the precursor protein for PDGF B-chain (Johnsson et al., 1984). In tissues other than platelets PDGF usually consists of a homodimer of two B-chains. PDGF stimulates proliferation in many cell types derived from mesoderm including fibroblasts, smooth muscle cells, glial cells and ovarian granulosa cells (Deuel \& Huang, 1984).

Goustin et al. (1985) found expression of PDGF in human placenta from as early as 21 days after conception. By in-situ hybridization the expression of the c-sis gene was localized to trophoblasts. Explants of first trimester placenta released radioreceptor-assayable PDGF, while cultured trophoblast cell lines were rich in high affinity PDGF receptors, and responded to exogenous PDGF with an increased expression of the proto-oncogene c-myc accompanied by DNA synthesis. Since the expression of $c-m y c$, which encodes a DNA binding protein and is one of the first intracellular events to take place following interaction of PDGF with its receptor, was also localized to trophoblasts this may represent an autocrine action of PDGF on trophoblast proliferation during the early invasive growth of the placenta. In later fetal development mRNA for PDGF was identified in the human kidney (Fraizer et al., 1987). While PDGF continues to be present in aortic smooth muscle in the immature rat, expression in later life appears to be limited, in normal circumstances, to platelets where it contributes to wound healing following platelet lysis.

Transforming growth factor $\beta$ (TGF- $\beta$ ) differs from the other growth factors outlined in that it predominantly acts as an inhibitor of cell proliferation. It is a homodimer of $M_{\mathrm{r}} 25000$ found in abundance in, and purified from, platelets. TGF- $\beta$ is a potent inhibitor of epithelial cell replication in vitro at picomolar concentrations (Strain et al., 1986). For mesodermal cells it can act as a bifunctional growth regulator, either enhancing the actions of other growth factors on cell replication or serving as a growth inhibitor depending on the cellular substratum, the age of development of the tissue, and whether the cells are virally transformed (Roberts et al., 1985). TGF- $\beta$ stimulates fibronectin and collagen release, major constituents of extracellular matrix, by some fibroblast types; increases the release of plasminogen activator from other fibroblasts leading to a degradation of extracellular matrix glycoproteins; and modulates cell adhesion molecule receptors. These properties suggest a potential role in tissue modelling and this is supported by the anatomical distribution of TGF- $\beta$ in the embryo and fetus.

TGF- $\beta$ mRNA was found in the vegetal pole ectoderm of Xenopus embryos and is transcribed by a maternally-derived gene Vg1 (Weeks \& Melton, 1987). An ectodermal cell line, XTC, obtained from a metamorphosing tadpole releases a TGF- $\beta$-like peptide in vitro (Rosa et al., 1988). In the 11-18-day mouse embryo TGF- $\beta$ has been localized immunohistochemically to differentiated and undifferentiated mesenchyme including bone and connective tissues, particularly that derived from neural crest such as palate, larynx, facial mesenchyme and teeth (Heine et al., 1987). Staining was most intense around sites of tissue morphogenesis involving mesodermal interaction with adjacent epithelia, including hair follicles, teeth and secondary palate. In late fetal rat development TGF- $\beta$ bioactivity was identified in multiple tissues, levels being greatest in muscle, lung, liver and kidney (Hill et al., 1986), while TGF- $\beta$ was released by isolated fetal rat calvaria and by myoblasts (Centrella \& Canalis, 1985; Hill et al., 1986). After birth, TGF- $\beta$ concentrations in rat tissues decline rapidly to barely detectable levels (Hill et al., 1986), although in the human TGF- $\beta$ remains widely distributed amongst cells of the immune system including monocytes and T-lymphocytes. It has been proposed that its presence in the latter constitutes an autocrine negative feedback system on the clonal expansion of lymphocytes in response to interleukin 2 (Kehrl et al., 1986).

\section{Mitogenesis}

The overlapping biological properties of growth factors such as IGFs, EGF, PDGF and FGF as cell mitogens may represent, at first sight, gross evolutionary overcapacity. However, some 
selectivity exists since differing cell types may recognize each growth factor with different relative sensitivity. Additionally, each growth factor appears to fulfil a particular role within the cycle of cell replication.

Many fundamental studies on cell cycle control have been performed using BALB/c-3T3 fibroblasts which were originally derived from an embryonic mouse. It was found that PDGF alone and at concentrations similar to those found in tissues was unable to initiate proliferation in quiescent, density arrested BALB/c-3T3 cells and that an addition of plasma was needed for cells to enter S phase and DNA synthesis (O'Keefe \& Pledger, 1983). Similarly, platelet-poor plasma alone could not stimulate cell replication although it maintained cell survival. A sequential addition of PDGF followed by platelet-poor plasma enabled cells to progress to $S$ phase with a lag period of $12 \mathrm{~h}$ following exposure to PDGF. The percentage of nuclei stimulated to initiate DNA synthesis depended on the concentrations of PDGF and plasma. Only a transient exposure to PDGF was necessary and the sensitizing effect lasted for 3-5 h. In contrast, plasma was required for the whole of the remaining period of $G_{1}$. It was concluded that PDGF induced a state of 'competence' which rendered quiescent cells capable of traversing the cell cycle from $G_{0}$ to $G_{1}$ in response to other plasma factors. FGF fulfilled a similar role for this cell type.

The need for plasma to enable synchronized BALB/c-3T 3 cells to progress through $\mathrm{G}_{1}$ could be replaced by a mixture of EGF and IGF-I, although the latter could be substituted by pharmacological concentrations of insulin (Van Wyk et al., 1981). The temporal order of exposure to these 'progression' factors was important for subsequent entry into DNA synthesis, EGF being necessary for the first $6 \mathrm{~h}$ of $\mathrm{G}_{1}$ and IGF-I for the remaining period until about $2 \cdot 5 \mathrm{~h}$ before the $\mathrm{G}_{1} / \mathrm{S}$ boundary when cell replication becomes growth factor-independent. The ability of cells to traverse the final part of $G_{1}$ without growth factor stimulation is probably due to the transcription of DNAsynthesizing enzymes such as thymidine kinase and thymidylate synthase having been completed by this time. Their transcription earlier in $G_{1}$ is stimulated by IGF-I (Yang \& Pardee, 1986). Growtharrested BALB/c-3T3 cells could therefore be induced to traverse the full cell cycle in defined culture medium containing only PDGF, EGF and IGF-I in sequential order. Each growth factor may render the cells responsive to the next since exposure of cells to PDGF caused a change in affinity of the EGF receptor for EGF (Sinnett-Smith \& Rozengurt, 1985), while plasma caused a doubling of IGF-I receptor number about $3 \mathrm{~h}$ into $\mathrm{G}_{1}$ and before the onset of IGF sensitivity (Van Wyk et al., 1981).

The ability of BALB/c-3T3 cells to traverse the cell cycle in growth factor-supplemented medium was dependent on the availability of amino acids, especially those in group B such as cysteine, isoleucine, lysine, phenylalanine and tyrosine (Cooper \& Wharton, 1985). In medium deficient in amino acids cells become arrested at a point midway through $G_{1}$ coincident with the time from which IGF-I is necessary. An additional amino acid-dependent restriction point was found in human fibroblasts $2-3 \mathrm{~h}$ before the $\mathrm{G}_{1} / \mathrm{S}$ boundary coincident with the completion of DNA-synthesizing enzyme transcription. This suggests that two periods within $G_{1}$ in particular require protein synthesis and that both may be dependent on IGF-I.

This model of growth factor action during BALB/c-3T3 cell proliferation does not hold true for all cell types although the concept on 'competence' and 'progression' factors appears to be universal. Human fibroblasts have a greater endogenous ability to release IGFs in vitro than do the embryonic mouse fibroblasts (Clemmons et al., 1981). Consequently, this obviates the absolute need for IGFs during the $G_{1}$ phase. Additionally, PDGF is necessary throughout $G_{1}$ as well as at the $G_{0} / G_{1}$ interface for optimal proliferation to occur (Westermark \& Heldin, 1985). Other cell types differ more radically; for instance, EGF appears to act as a competence factor for isolated hepatocytes while IGF-I fulfils this role for chondrocytes.

The mitogenic actions of some growth factors are influenced by associations with specific binding proteins or extracellular matrix components. An IGF binding protein of $M_{\mathrm{r}} 26000$ is released by multiple cell types in vitro and is found throughout extracellular fluids and the circulation (Ooi \& Herington, 1988). It greatly extends the biological half-life of the IGF peptides. One form of this 
binding protein, purified from human amniotic fluid, avidly attaches to some cell membranes in vitro including those of fibroblasts (Clemmons et al., 1986). Exogenous binding protein enhanced the mitogenic capacity of IGF-I on adult human fibroblasts, while other closely related species, also isolated from amniotic fluid, did not associate with cell membranes and antagonized IGF-I biological activity (Elgin $e t$ al., 1987). This may represent an additional level of growth control by which cells can up- or down-regulate IGF action by the synthesis of specific binding proteins.

A different mechanism may be responsible for prolonging the biological half-life of FGF within tissues. FGF avidly associates with heparin sulphate, a glycosaminoglycan produced in large amounts by vascular and corneal endothelium and a structural component of their extracellular matrix. The FGF gene does not encode a conventional signal peptide sequence which is necessary for vesicle-associated exocytosis (Gospodarowicz et al., 1987). The peptide may therefore leave the cell associated with extracellular matrix molecules and either interact immediately with FGF receptors as an autocrine stimulus or remain stored within the matrix: the FGF bound to matrix components retains full biological activity. Since organogenesis involves an interaction of cells with newly synthesized extracellular matrix to promote stem-cell growth and stabilize their specialized phenotype it is possible that FGF could exert mitogenic and differentiating effects from a matrix store.

\section{Tissue induction}

Two peptide growth factors, FGF and TGF- $\beta$, have been shown to promote the induction of mesoderm from primitive ectoderm in the early embryo. Such induction in the amphibian embryo depends on diffusible morphogens from the vegetal pole ectoderm causing mesodermal development from the animal pole ectoderm. FGF is a mesoderm-inducing factor for cultured animal pole ectoderm from Xenopus embryos; the structures which develop being primarily derived from ventral mesoderm and consisting of concentric patterns of loose mesenchyme, mesothelium and blood cells enclosed by ectoderm. Some dorsal mesodermal structures, such as muscle cells, were also identified (Slack et al., 1987). TGF- $\beta$ also induced mesoderm formation in Xenopus ectoderm, especially muscle which was identified by the presence of $\alpha$-actin mRNA (Rosa et al., 1988). A synergism existed between FGF and TGF- $\beta$ in this respect (Kimelman \& Kirschner, 1987). The most potent natural source of mesoderm-inducing activity is conditioned medium from Xenopus XTC cell cultures, a known source of TGF- $\beta$. The ability of TGF- $\beta$ antiserum to block the mesoderm-inductive capacity of XTC-conditioned medium suggests that an amphibian TGF- $\beta$ may be the major bioactive moiety (Rosa et al., 1988).

\section{Tissue differentiation}

Growth factors can augment or antagonize the onset of differentiated cell function. A potentiation of differentiation need not exclude a mitogenic role since an immediate action on proliferation may be followed by a later tendency to promote terminal differentiation. Separate growth factors can co-operate or compete during the induction of differentiated function, while some show synergistic interaction with endocrine hormones. While growth factor action is most obvious during the progressive differentiation of the fetus and neonate, considerable interest has been shown in tissues which retain a high degree of anatomical and functional rearrangement in adult life, such as the ovarian follicles.

A well-studied model of tissue differentiation in vitro is the fusion of myoblasts into polynuclear, post-mitotic myotubes. This process can be quantitated by measuring the rise in myotube-associated enzymes such as myokinase and creatinine phosphokinase, or the acquisition of acetyl choline receptors. Muscle differentiation largely occurs in utero in man but can still be observed in the first 
week post partum in the rat. Physiological concentrations of IGF-I or pharmacological concentrations of insulin promoted the proliferation of newly isolated myoblasts and of established myoblast cell lines (Ewton \& Florini, 1980; Hill et al., 1985). However, after 1 or 2 replicative cycles myoblasts ceased to proliferate in response to IGF-I and were instead stimulated to differentiate terminally (Ewton \& Florini, 1981). This action of IGF-I on myoblast differentiation was still apparent when proliferation was abolished by exposure of cells to cytosine arabinoside. Primary and established myoblast cultures also proliferated in response to FGF. However, FGF inhibited myoblast differentiation to maintain an expanding population of cells (Linkhardt et al., 1981). TGF- $\beta$ exerted rapid anabolic actions on isolated myoblasts, such as an increase in amino acid transport, but had little effect on myoblast proliferation and inhibited myoblast differentiation (Massague et al., 1986). When myoblasts differentiated spontaneously at high cell density the number of cellular receptors for TGF- $\beta$ was greatly reduced, a process also noted for EGF and FGF receptors (Ewton et al., 1988). Differentiation of tissues may therefore be associated with gross changes in growth factor responsiveness.

The myoblast model demonstrates that separate growth factors, which in the short term have similar mitogenic actions, can have opposite effects on long-term tissue phenotype, FGF blocking and IGF-I stimulating differentiation. Two observations suggest that IGFs are also involved in the differentiation of brain cell types. Firstly, when isolated cells from 1-day-old rat cerebellum were exposed to IGF-I glial cell differentiation was directed towards the production of oligodendrocytes rather than astrocytes (McMorris et al., 1986). Secondly, IGF-II synergized with nerve growth factor to promote neurite outgrowth from rat sensory and sympathetic ganglia (Recio-Pinto \& Ishii, 1984). IGF-I has also been reported to potentiate the differentiation of fetal rat calvaria, chondrocytes, and erythroid precursor cells.

EGF modulates the differentiation of epithelial structures in the fetus and neonate. When administered to the fetal lamb for 2 weeks in the last third of pregnancy EGF caused hypertrophy of skin epithelium and the growth of the adrenal, thyroid, liver and kidney (Thorburn et al., 1981). In the fetal rabbit and lamb exogenous EGF induced lung epithelium maturation and surfactant production (Catterton et al., 1979; Sundell et al., 1980), while in cultures of embryonic chick skin EGF inhibited glucocorticoid-induced epidermal keratinization (Obinata et al., 1987). Receptors for EGF are abundant in human placenta, especially on the microvillus plasma membranes in contact with the maternal circulation, and on the basolateral membranes adjacent to the fetal circulation (Roa et al., 1984). This distribution implies an interaction between EGF and the syncytiotrophoblast, and studies with isolated trophoblasts and placental cultures have shown that EGF modulates trophoblast differentiation and function. In homogeneous cultures of term trophoblasts, EGF caused a dose-related release of human placental lactogen and chorionic gonadotrophin (Morrish et al., 1987). There was no change in trophoblast cell number within these experiments but EGF induced a differentiation of cytotrophoblasts to form a syncytium. Parallel experiments with early and late placental explants yielded similar results for hormone release (Maruo et al., 1987). It is not known whether the EGF that interacts with placenta in vivo is fetal, maternal or placental in origin. However, infusion of EGF into the fetal lamb caused an increased release of placental lactogen into the maternal circulation. EGF is abundant in milk, especially colostrum, and may contribute to the proliferation and maturation of the neonatal gut.

The cyclic nature of the female reproductive system relies on the ability of ovarian follicles to change rapidly in structure and function. While gonadotrophins are the primary initiators of follicular development, growth factors have a permissive or mediatory role in these responses during follicular growth and maturation, and also during ovulation. Granulosa cells from human and animal species have specific receptors for IGF-I, the binding capacities of which are elevated by FSH or LH and further augmented by oestrogens (Adashi et al., 1988). IGF-I was reported to stimulate directly granulosa cell proliferation, but not that of thecal cells (Hernandez et al., 1988). It had little effect alone on steroidogenesis by isolated rat granulosa cells but synergized with FSH to increase LH receptor number and, consequently, progesterone synthesis, aromatase activity and 
oestrogen accumulation (Adashi et al., 1985; Veldhuis et al., 1986). The ability of IGF-I to enhance the appearance of $\mathrm{LH}$ receptors was augmented by oestrogens and/or thecal cell-derived androgens. In turn, IGF-I was reported to increase basal and LH-stimulated androstenedione release by thecal cells. On isolated porcine granulosa cells IGF-I increased granulosa cell differentiated function without the presence of FSH (Veldhuis et al., 1986).

Thecal-interstitial cells within the follicle release TGF- $\beta$ (Skinner et al., 1987), which has little action on granulosa cell proliferation but, like IGF-I, synergizes with FSH to increase LH receptor number and steroidogenesis by granulosa cells (Knecht et al., 1987). These actions are attenuated by FGF. A molecule which is structurally related to TGF- $\beta$ is inhibin which is reported to be released from granulosa cells under FSH control and to block steroidogenesis by these cells (Hillier et al., 1987; Bicsak et al., 1988). The FSH-stimulated release of inhibin was potentiated by IGF-I, oestradiol and androstenedione, but blocked by EGF, or its analogue TGF- $\alpha$, which is expressed by the thecal-interstitial cells (Kudlow et al., 1987). EGF stimulated granulosa cell proliferation in most species examined except rat, and this action was suppressed by FSH. While some species variation exists, EGF generally blocked FSH-stimulated granulosa cell differentiation (Franchimont et al., 1986). Partly pure preparations of PDGF were reported to enhance granulosa cell proliferation and differentiated function but the physiological presence of PDGF in ovary is uncertain. Peptide growth factors have been implicated in the maturation of the rat oocyte, assessed by the breakdown of nuclear germinal vesicles as a marker of meiotic re-activation. TGF- $\beta$ caused an acceleration of maturation in follicle-enclosed oocytes and cumulus-oocyte complexes (Feng et al., 1988). This action was probably indirect since TGF- $\beta$ had no influence on cumulus-free oocytes. IGF-I and -II also stimulated oocyte maturation while PDGF and insulin had no effect.

Within the male reproductive system IGF-I and an EGF-like molecule, both released by Sertoli cells, can influence Leydig cell activity. Exogenous IGF-I increased LH/hCG binding and hCGstimulated testosterone release by isolated rat Leydig cells (Morera et al., 1987). These actions were independent of the proliferative action of IGF-I on Leydig cells.

\section{Chemotaxis}

The potent chemotactic properties of growth factors such as PDGF and TGF- $\beta$ for mesenchymal tissues suggests a possible role in the cell migration of embryogenesis, but this remains unproven. However, growth factor-induced chemotaxis may be central to the cascade of paracrine interactions which accompany wound healing. Following the disruption of the vascular endothelium platelet lysis occurs within damaged tissues to release high local concentrations of PDGF, TGF- $\beta$ and EGF. Additionally, damaged endothelium itself expresses the $\mathrm{c}$-sis oncogene and may release PDGF. PDGF is a potent chemotactic agent in vivo for inflammatory cells such as monocytes and neutrophils, and mesenchymal cell types including fibroblasts and smooth muscle cells (Deuel $e t$ al., 1987). At higher concentrations PDGF activated superoxide generation, specific granule release and mobilization of calcium stores by neutrophils and monocytes. Such mobilizing actions of PDGF on inflammatory cells are reinforced by TGF- $\beta$, which when included in wound chambers implanted into rats exerted chemoattractant properties for neutrophils, monocytes and fibroblasts (Sporn et al., 1983). Monocytes and macrophages are further potential sources of PDGF, TGF- $\beta$ and FGF release.

Chemoattraction may therefore lead to extremely high local concentrations of several growth factors at injury sites. When coupled with an abundant presence of IGFs derived from the circulation this may create an optimal synergistic interaction of growth factors necessary to initiate mesenchymal and epithelial proliferation and promote wound healing. In addition, TGF- $\beta$ promoted the synthesis of collagens and fibronectin, creating fresh extracellular matrix (Ignotz et al., 1987). Ectopic application of EGF in saliva could potentiate epithelial regeneration. Once the vascular endothelium is again intact platelet lysis will cease, the chemoattraction of inflammatory 
cells will decrease and the tissue growth factor presence will return to equilibrium. Support for such a model of wound healing is provided by the ability of exogenous, PDGF, TGF- $\beta$ or EGF/TGF- $\alpha$ to reduce wound healing time and increase the tensile strength of new tissue (Roberts et al., 1986; Lynch et al., 1987; Mustoe et al., 1987; Schultz et al., 1987).

\section{Comment}

Peptide growth factors provide an infinitely variable, fundamental level of intercellular communication influencing all aspects of cell behaviour throughout life and preceding the appearance of the endocrine system. Their sphere of influence is predominantly within each local tissue environment and this level of control, coupled with interactions between cells and extracellular matrix components, provides the fundamental drive to embryonic development. In later fetal and postnatal life peptide growth factor presence or action may become sub-ordinate to endocrine hormones. The finding of peptides analogous to IGFs, EGF and TGF- $\beta$ in invertebrates suggests that growth factors represent a primaeval control system which has been retained throughout animal evolution.

\section{References}

Adamson, E.D. \& Meek, J. (1984) The ontogeny of epidermal growth factor receptors during mouse development. Devl Biol. 103, 62-70.

Adashi, E.Y., Resnick, C.E., Hernandez, E.R., Svoboda, M.E. \& Van Wyk, J.J. (1985) Insulin-like growth factors as intraovarian regulators of granulosa cell growth and function. Endocr. Rev. 6, 400-420.

Adashi, E.Y., Resnick, C.E., Hernandez, E.R., Svoboda, M.E. \& Van Wyk, J.J. (1988) Characterization and regulation of a specific cell membrane receptor for somatomedin-C/insulin-like growth factor I in cultured rat granulosa cells. Endocrinology 122, 194-201.

Andersson, I., Billig, H., Fryklund, L., Hansson, H-A., Isaksson, O., Isgaard, J., Nilsson, A., Rozell, B., Skottner, A. \& Stemme, S. (1986) Localization of IGF-I in adult rats. Immunohistochemical studies. Acta physiol. scand. 126, 311-312.

Beck, F., Samani, N.J., Penschow, J.D., Thorley, B., Tregear, G.W. \& Cochlan, J.P. (1987) Histochemical localization of IGF I and II mRNA in the developing rat embryo. Development 101, 175-184.

Bicsak, T.A., Cajander, S.B., Vale, W. \& Hsueh, A.J.W. (1988) Inhibin: studies of stored and secreted forms by biosynthetic labelling and immunodetection in cultured rat granulosa cells. Endocrinology 122, 741-748.

Catterton, W.Z., Escobedo, M.B., Sexson, W.R., Gray, M.E., Sundell, H.W. \& Stahlman, M.T. (1979) Effect of epidermal growth factor on lung maturation in fetal rabbits. Pediat. Res. 13, 104-108.

Centrella, M. \& Canalis, E. (1985) Transforming and non-transforming growth factors are present in medium conditioned by fetal rat calvariae. Proc. natn. Acad. Sci. U.S.A. 82, 7335-7339.

Clemmons, D.R., Elgin, R.G., Han, V.K.M., Casella, S.J., D'Ercole, A.J. \& Van Wyk, J.J. (1986) Cultured fibroblast monolayers secrete a protein that alters the cellular binding of somatomedin-C/insulin-like growth factor I. J. clin. Invest. 77, 1548-1556.
Clemmons, D.R., Underwood, L.E. \& Van Wyk, J.J. (1981) Hormonal control of immunoreactive somatomedin production by cultured human fibroblasts. $J$. clin. Invest. 67, 10-19.

Cohen, S. (1962) Isolation of a submaxillary gland protein accelerating incisor eruption and eyelid opening in the newborn animal. J. biol. Chem. 237, $1555-1562$.

Cooper, J.L. \& Wharton, W. (1985) Late $\mathrm{G}_{1}$ amino acid restriction point in human dermal fibroblasts. J. cell. Physiol. 124, 433-438.

D'Ercole, A.J., Stiles, A.D. \& Underwood, L.E. (1984) Tissue concentrations of somatomedin-C: further evidence for multiple sites of synthesis and paracrine/ autocrine mechanisms of action. Proc. natn. Acad. Sci. U.S.A. 81, 935-939.

Deuel, T.F. \& Huang, J.S. (1984) Platelet-derived growth factor. Structure, function, and roles in normal and transformed cells. J. clin. Invest. 74, 669-676.

Deuel, T.F., Pierce, G.F., Yeh, H-J., Shawver, L.K., Milner, P.G. \& Kimura, A. (1987) Platelet-derived growth factor/sis in normal and neoplastic cell growth. J. cell. Physiol., Suppl. 5, 95-99.

Eden, J.A., Carter, G.D., Jones, J., Price, J. \& AlaghbanZadeh, J. (1988) The relationship between follicular growth and insulin-like growth factor I (IGF I) in human follicular fluid. J. Endocr. 117 (Suppl.), 242, Abstr.

Elgin, R.G., Busby, W.H. \& Clemmons, D.R. (1987) An insulin-like growth factor (IGF) binding protein enhances the biological response to IGF I. Proc. natn. Acad. Sci. U.S.A. 84, 3254-3258.

Engstrom, W., Bell, K.M. \& Schofield, P.N. (1987) Expression of the insulin like growth factor II gene in the developing chick limb. Cell. Biol. Int. Rep. 11, 415- 421 .

Esch, F., Baird, A., Ling, N., Veno, N., Hill, F., Denoroy, L., Klepper, R., Gospodarowicz, D., Bohlen, P. \& Guillemin, R. (1985) Primary structure of bovine 
pituitary basic fibroblast growth factor (FGF) and comparison with the amino-terminal sequence of bovine brain acidic FGF. Proc. natn. Acad. Sci. U.S.A. 82, 6507-6511.

Ewton, D.Z. \& Florini, J.R. (1980) Relative effects of somatomedin, multiplication stimulating activity, and growth hormone on myoblasts and myotubes in culture. Endocrinology 106, 577-583.

Ewton, D.Z. \& Florini, J.R. (1981) Effects of somatomedins and insulin on myoblast differentiation in vitro. Devl Biol. 56, 31-39.

Ewton, D.Z., Spizz, G., Olson, E.N. \& Florini, J.R. (1988) Decrease in transforming growth factor- $\beta$ binding and action during differentiation in muscle cells. $J$. biol. Chem. 263, 4029-4032.

Feng, P., Catt, K.J. \& Knecht, M. (1988) Transforming growth factor- $\beta$ stimulates meiotic maturation of the rat oocyte. Endocrinology 122, 181-188.

Fraizer, G.E., Bowen-Pope, D.F. \& Vogel, A.M. (1987) Production of platelet-derived growth factor by cultured Wilm's tumour cells and fetal kidney cells. $J$. cell. Physiol. 133, 169-174.

Franchimont, P., Hazee-Hagelstein, M.T., CharletRenard, C. \& Jasper, J.M. (1986) Effect of mouse epidermal growth on DNA and protein synthesis, progesterone and inhibin production by bovine granulosa cells in culture. Acta endocr., Copenh. 111, 122-127.

Gospodarowicz, D., Cheng, J., Lui, G-M., Baird, A. \& Bohlent, P. (1984) Isolation of brain fibroblast growth factor by heparin-sepharose affinity chromatography: identity with pituitary fibroblast growth factor. Proc. natn. Acad. Sci. U.S.A. 81, 6963-6967.

Gospodarowicz, D., Neufeld, G. \& Schweigerer, L. (1987) Fibroblast growth factor: structural and biological properties. J. cell. Physiol., Suppl. 5, 15-26.

Goustin, A.S., Betsholtz, C., Pfeifer-Ohlsson, S., Persson, H., Rydnert, J., Bywater, M., Holmgren, G., Heldin, C-H., Westermark, B. \& Ohlsson, R. (1985) Coexpression of the sis and myc protooncogenes in developing human placenta suggests autocrine control of trophoblast growth. Cell 41, 301-312.

Gregory, H. (1975) Isolation and structure of urogastrone and its relationship to epidermal growth factor. Nature, Lond. 257, 325-327.

Han, V.K.M., D'Ercole, A.J. \& Lund, P.K. (1987a) Cellular localisation of somatomedin (insulin-like growth factor) messenger RNA in the human fetus. Science, N.Y. 236, 193-197.

Han, V.K.M., Hill, D.J., Strain, A.J., Towle, A.C., Lauder, J.M., Underwood, L.E. \& D'Ercole, A.J. (1987b) Identification of somatomedin/insulin-like growth factor immunoreactive cells in the human fetus. Pediatr. Res. 22, 245-249.

Han, V.K.M., Hunter, E.S., Pratt, R.M., Zendegui, J.G. \& Lee, D.C. (1987c) Expression of rat transforming growth factor alpha mRNA during development occurs predominantly in the maternal decidua. Molec. cell. Biol. 7, 2335-2343.

Hansson, H-H., Dahlin, L.B., Danielson, N., Fryklund, L., Nachemson, A.K., Polleryd, P., Rozell, B., Skottner, A., Stemme, S. \& Lundborg, G. (1986) Evidence indicating trophic importance of IGF $I$ in regenerating peripheral nerves. Acta physiol. scand. 126, 609-614.
Hansson, J-H., Jennische, E. \& Skottner, A. (1987) Regenerating endothelial cells express insulin-like growth factor I immunoreactivity after arterial injury. Cell Tiss. Res. 250, 499-505.

Heine, V.I., Munoz, E.F., Flanders, K.C., Ellingsworth, L.R., Lam, H-Y.P., Thompson, N.L., Roberts, A.B. \& Sporn, M.B. (1987) Role of transforming growth factor- $\beta$ in the development of the mouse embryo. $J$. Cell Biol. 105, 2861-2876.

Hernandez, E.R., Resnick, C.E., Svoboda, M.E., Van Wyk, J.J., Payne, D.W. \& Adashi, E.Y. (1988) Somatomedin-C/insulin-like growth factor I as an enhancer of androgen biosynthesis by cultured rat ovarian cells. Endocrinology 122, 1603-1612.

Hill, D.J., Crace, C.J., Nissley, S.P., Morrell, D., Holder, A.T. \& Milner, R.D.G. (1985) Fetal rat myoblasts release both rat somatomedin-C (SM-C)/insulin-like growth factor I (IGF I) and multiplication-stimulating activity of myoblast-derived SM-C/IGF I. Endocrinology 117, 2061-2072.

Hill, D.J., Strain, A.J. \& Milner, R.D.G. (1986) Presence of transforming growth factor- $\beta$-like activity in multiple fetal rat tissues. Cell. Biol. Internat. Rep. 10, 915-922.

Hill, D.J., Wilson, S., Strain, A.J. \& Clemmons, D.R. (1988) Immunolocalisation of insulin-like growth factor binding protein (IGF-BP) in human fetal tissues. J. Endocr. 116 (Suppl.), 244, Abstr.

Hillier, S.G., Tsonis, C.G., Wickings, E.J. \& Eidne, K.A. (1987) Inhibition of FSH-stimulated granulosa cell function by a synthetic fragment of the porcine inhibin $\alpha$-subunit: evidence for involvement of GnRH receptors. $J$. Endocr. 113, 123-125.

Hsu, C-J. \& Hammond, J.M. (1987) Concomitant effects of growth hormone on secretion of insulin-like growth factor I and progesterone by cultured porcine granulosa cells. Endocrinology 121, 1343-1348.

Ignotz, R.A., Endo, T. \& Massague, J. (1987) Regulation of fibronectin and type 1 collagen mRNA levels by transforming growth factor- $\beta$. J. biol. Chem. 262, 6443-6446.

Isaksson, O.G.P., Lindahl, A., Nilsson, A. \& Isgaard, J. (1987) Mechanism of the stimulatory effect of growth hormone on longitudinal bone growth. Endocr. Rev. 8, 426-438.

Jennische, E. \& Oliverecrone, H. (1987) Transient expression of insulin-like growth factor I immunoreactivity in skeletal muscle cells during postnatal development in the rat. Acta physiol. scand. 131, 619, Abstr.

Johnsson, A., Heldin, C-H., Wasteson, A., Westermark, B., Deuel, T.F., Huang, J.S., Seeburg, P.H., Gray, A. Ullrich, A., Scrace, G., Stroobant, P. \& Waterfield, M.D. (1984) The c-sis gene encodes a precursor of the $\mathrm{B}$ chain of platelet-derived growth factor. $E M B O J$. 3, 921-928.

Kasselberg, A.G., Orth, D.N., Gray, M.E. \& Stahlman, M.T. (1985) Immunocytochemical localization of human epidermal growth factor/urogastrone in several human tissues. J. Histochem. Cytochem. 33, 315-322.

Kehrl, J.H., Wakefield, L.M., Roberts, A.B., Jakowlew, S., Alvarezmon, M., Derynck, R., Sporn, M.B. \& Fauci, A.S. (1986) Production of transforming growth factor $\beta$ by human $\mathrm{T}$ lymphocytes and its 
potential role in the regulation of $\mathrm{T}$ cell growth. $J$. exp. Med. 1986, 1037-1050.

Kimelman, D. \& Kirschner, M. (1987) Synergistic induction of mesoderm by FGF and TGF-beta and the identification of an mRNA coding for FGF in the early xenopus embryo. Cell 51, 869-871.

Knecht, M., Feng, P. \& Catt, K. (1987) Bifunctional role of transforming growth factor- $\beta$ during granulosa cell development. Endocrinology 120, 1243-1249.

Kudlow, J.E., Kobrin, M.S., Purchio, A.F., Twardzik, D.R., Hernandez, E.R., Asa, S.L. \& Adashi, E.Y. (1987) Growth factor ovarian transforming- $\alpha$ gene expression: immunohistochemical localization to the theca-interstitial cells. Endocrinology 121, 1577-1579.

Linkhardt, T.A., Clegg, C.H. \& Hauscha, S.D. (1981) Myogenic differentiation in permanent clonal mouse myoblast cell lines: regulation by macromolecular growth factors in the culture medium. Devl Biol. 86, 19-30.

Lynch, S.E., Nixon, J.C., Colvin, R.B. \& Antoniades, H.N. (1987) Role of platelet-derived growth factor in wound healing: synergistic effects with other growth factors. Proc. natn. Acad. Sci. U.S.A. 84, 7696-7700.

Marquardt, H., Hunkapiller, M.W., Hood, L.E. \& Todaro, G.J. (1984) Rat transforming growth factor type 1: structure and relation to epidermal growth factor. Science, N.Y. 223, 1079-1081.

Maruo, T., Matsuo, H., Oishi, T., Hayashi, M., Nishino, R. \& Mochizuki, M. (1987) Induction of differentiated trophoblast function by epidermal growth factor: relation of immunohistochemically detected cellular epidermal growth factor receptor levels. $J$. clin. Endocr. Metab. 64, 744-750.

Massague, J., Chiefetz, S., Endo, T. \& Nadel-Ginard B. (1986) Type $\beta$ transforming growth factor is an inhibitor of myogenic differentiation. Proc. natn. Acad. Sci. U.S.A. 83, 8206-8210.

MeMorris, F.A., Smith, T.M., De Salvo, S. \& Furlanetto, R.W. (1986) Insulin-like growth factor I/somatomedin C: a potent inducer of oligodendrocyte development. Proc. natn. Acad. Sci. U.S.A. 83, 822-826.

Morera, A.M., Chauvin, M.A., Peretti, E., Binoux, M. \& Benahmed, M. (1987) Somatomedin C/insulin-like growth factor 1: an intratesticular differentiative factor of leydig cells. Horm. Res. 28, 50-57.

Morrish, D.W., Bhardwaj, D., Dabbagh, L.K., Marusyk, H. \& Siy, O. (1987) Epidermal growth factor induces differentiation and secretion of human chorionic gonadotropin and placental lactogen in normal human placenta. J. clin. Endocr. Metab. 65, 1282-1290.

Mustoe, T.A., Pierce, G.F., Thomason, A., Grametes, P., Sporn, M.B. \& Deuel, T.F. (1987) Accelerated healing of incisional wounds in rats induced by transforming growth factor $\beta$. Science, N.Y. 237, 1333-1336.

Obinata, A., Akimoto, Y., Hoshino, A., Hirano, H. \& Endo, H. (1987) Inhibition by epidermal growth factor of glucocorticoid-induced epidermal $\alpha$-type keratinization of chick embryonic skin cultured in the presence of delipidized fetal calf serum. Devl Biol. 124, 153-162.

O'Keefe, E. \& Pledger, W.J. (1983) A model of cell cycle control: sequential events regulated by growth factors. Molec. cell. Endocr. 31, 167-186.

Oliver, J.E., Powell, J.F. \& Clayton, R.N. (1988)
Expression of the insulin-like growth factor I gene in the rat ovary. J. Endocr. 117 (Suppl.), 32, Abstr.

Ooi, G.T. \& Herington, A.C. (1988) The biological and structural characterization of specific serum binding proteins for the insulin-like growth factors. $J$. Endocr. 118, 7-18.

Recio-Pinto, E. \& Ishii, D.N. (1984) Effects of insulin, insulin-like growth factor-Il and nerve growth factor on neurite outgrowth in cultured human neuroblastoma cells. Brain Res. 302, 323-334.

Roa, C.V., Carman, F.R., Ghegini, N. \& Schultz, G.S. (1984) Binding sites for epidermal growth factor in human fetal development. J, clin. Endocr. Metab. 58, $1034-1042$.

Roberts, A.B., Anzano, M.A., Wakefield, L.M., Roche, N.S., Stern, D.F. \& Sporn, M.B. (1985) Type $\beta$ transforming growth factor: a bifunctional regulator of cellular growth. Proc. natn. Acad. Sci. U.S.A. 82, 119-123.

Roberts, A.B., Sporn, M.B., Assoian, R.K., Smith, J.M., Roche, N.S., Wakefield, L.M., Heine, V.I., Liotta, L.A., Falanga, V., Kehrl, J.H. \& Fauci, A.S. (1986) Transforming growth factor type $\beta$ : rapid induction of fibrosis and angiogenesis in vivo and stimulation of collagen formation in vitro. Proc. natn. Acad. Sci. U.S.A. 83, 4167-417l.

Rolfe, J.R., Wylie, L., Hill, D.J. \& Tickle, C. (1988) Distribution of insulin-like growth factor during cranio facial development in the chick embryo. Proc. Federation of European Connective Tissue Societies, Amsterdam. (in press).

Rosa, F., Roberts, A.B., Danielpour, D., Dart, L.L., Sporn, M.B. \& Dawid, I.B.(1988) Mesoderm induction in amphibians: the role of TGF- $\beta 2$-like molecules. Science, N.Y. 239, 783-785.

Rotwein, P., Pollock, K.M., Watson, M. \& Millbrandt, J.D. (1987) Insulin-like growth factor gene expression during rat embryonic development. Endocrinology 121, 2141-2144.

Schultz, G.S., White, M., Mitchell, R., Brown, G., Lynch, J., Twardzik, D.R. \& Todaro, G.J. (1987) Epithelial wound healing enhanced by transforming growth factor- $\alpha$ and vaccinia growth factor. Science, N.Y. 235, 350-352.

Sinnett-Smith, J.W. \& Rozengurt, E. (1985) Diacylglycerol treatment rapidly decreases the affinity of the epidermal growth factor receptors of swiss 3T3 cells. J. cell. Physiol. 124, 81-86.

Skinner, M.K., Keski-Oja, J., Osteen, K.G. \& Moses, H.L. (1987) Ovarian thecal cells produce transforming growth factor-beta which can regulate granulosa cell growth. Endocrinology 121, 786-792.

Slack, J.M.W., Darlington, B.G., Heath, J.K. \& Godsave, S.F. (1987) Mesoderm induction in early xenopus embryos by heparin-binding growth factors. Nature, Lond. 326, 197-201.

Smith, E.P.,Svoboda, M.E., Van Wyk, J.J., Kierszenbaum, A.L. \& Tres, L.L. (1987) Partial characterization of a somatomedin-like peptide from the medium of cultured rat sertoli cells. Endocrinology 120, 186-193.

Sporn, M.B., Roberts, A.B., Shull, J.H., Smith, J.M. \& Ward, J.M. (1983) Polypeptide transforming growth factors isolated from bovine sources and used for wound healing in vivo. Science, N.Y. 219, 1329-1331. 
Strain, A.J., Hill, D.J. \& Milner, R.D.G. (1986) Divergent action of transforming growth factor $\beta$ on human foetal liver cells. Cell Biol. Int. Rep. 10, 855-860.

Sundell, H.W., Gray, M.E., Serenius, F.S., Escobedo, M.B. \& StahIman, M.T. (1980) Effects of epidermal growth factor on lung maturation in fetal lambs. $\mathrm{Am}$. J. Path. 100, 707-726.

Thorburn, G.C., Waters, M.J., Young, I.R., Dolling, M., Buntine, D. \& Hopkins, P.S. (1981) Epidermal growth factor: a critical factor in fetal maturation? In The Fetus and Independent Life (Ciba Fdn Symp. No. 86), pp. 172-191. Ed. J. Whelan. Pitman, London.

Tricoli, J.V., Rall, L.B., Scott, J., Bell, G.I. \& Shows, T.B. (1984) Localization of insulin-like growth factor genes to human chromosomes 11 and 12. Nature, Lond. 310, 784-786.

Van Wyk, J.J., Underwood, L.E., D'Ercole, A.J., Clemmons, D.R., Pledger, W.M., Wharton, W.R. \& Loef, E.B. (1981) Role of somatomedin in cellular proliferation. In Biology of Normal Human Growth, pp. 223-239. Eds M. Ritzen, A. Aperia, K. Hall, A. Larsson, A. Zetterburg \& R. Zellerstrom. Raven Press, New York.
Veldhuis, J.D., Rodgers, R.J. \& Furlanetto, R.W. (1986) Synergistic actions of estradiol and the insulin-like growth factor somatomedin-C on swine ovarian (granulosa) cells. Endocrinology 119, 530-538.

Waterfield, M.D., Scrace, T., Whittle, N., Stroobant, P., Johnsson, A., Wasteson, A., Westermark, B., Heldin, C.H., Huang, J.S. \& Deuel, T. (1983) Platelet-derived growth factor is structurally related to the putative transforming protein of $\mathrm{p} 28^{\text {sis }}$ of simian sarcoma virus. Nature, Lond. 304, 35-39.

Weeks, D.L. \& Melton, D.A. (1987) A maternal mRNA localized to the vegetal hemisphere in xenopus eggs codes for a growth factor related to TGF-beta. Cell 51, 861-868.

Westermark, B. \& Heldin, C-H. (1985) Similar action of platelet-derived growth factor and epidermal growth factor in the prereplicative phase of human fibroblasts suggests a common intracellular pathway. $J$. cell. Physiol. 124, 43-48.

Yang, H.C. \& Pardee, A.B. (1986) Insulin-like growth factor I regulation of transcription and replicating enzyme induction necessary for DNA synthesis. $J$. cell. Physiol. 127, 410-416. 